\section{Anomalous Water}

SiR,-K. S. Chua (Nature, 227, 834; 1970) has proposed certain structures to account for the density of anomalous water $\left(1.4 \mathrm{~g} \mathrm{~cm}^{-3}\right)$ with a resulting oxygen-oxygen bond length of $2 \cdot 4 \AA$. We add that the work of J. C. Speakman et al. (University of Glasgow) also reveals shared O-H-O bonds of similar lengths for certain erystalline acid salts.

Although unmentioned in the article, however, it turns out that the first of Chua's structures simply reduces to a scaled down $(2 \cdot 4 / 2 \cdot 76)$ version of the well known ice structure (but with hydrogens shared between the oxygens).
The second is the similar equivalent of the ice Ic structure - a low temperature polymorph of ice.

Can one really believe that these particular crystal structures as such could demonstrate the properties of liquid anomalous water?

$$
\begin{aligned}
& \text { Yours faithfully, } \\
& \text { IAN CHERRY } \\
& \text { PAUL BARNES } \\
& \text { JOHN FULI.MAN }
\end{aligned}
$$

Department of Crystallography,

Birkbeck College,

Malet Street, London WC1.
Obituary

\section{Dr K. Biswas}

Dr Kit.rpanda Biswas, the Indian botanist famous for his study of the flora of India and Burma, died on December 29 last year at tho age of seventy.

Early in his career he was superintendent to a number of botanical gardens in India, including the Royal Botanic Gardens of Calcutta and the Indian Botanic Gardens. For this work, he was awarded the Elliott gold medal and prize in 1928 and 1936, and the coronation medal in 1937. He came to Europe in 1936 and worked in the Herbarium of the Royal Botanic Gardens of Kew and Edinburgh and in the British Museum. In 1937 he was awarded a DSc at the University of Edinburgh for his valuable contribu. tions to the knowledge of the Indian flora, and in
1938 he was elected a fellow of the Royal Society of Edinburgh.

In 1954 he was appointed director of the Botanical Survey of India and in the following year he became director of medicinal plants, a post he held until his retirement. During this time, his task was to develop the large scale cultivation of ipecac. His success hero was important to the economy of India and earned him the Barclay memorial medal for the best research work in biological science in Asia in 1961.

After 1964, he continued as honorary lecturer in botany at the University of Calcutta and as a member of various organizations in India, Britain and UNESCO.

He had been suffering from a heart disease and chronic uraemia for one and a half years. II. leaves his wife, two sons and a daughter.

\section{Announcements}

\section{University News}

Professor C. Rimington, formerly of University College Hospital Medical School, London, will join the Department of General Medicine, University of Capetown, for about four months as Royal Society Lever. hulme visiting professor.

Dr D. B. Moffatt has been appointed to a personal chair in the Department of Anatomy, University College, Cardiff.

Dr R. F. Churchhouse, head of the Programming Group of the SRC Atlas Computer Laboratory, Oxford, has been appointed director of the Computing Centre and professor of computing mathematics.

Dr Elmar Seitler, assistant chief of biophysics in the US Armed Forces Institute of Pathology, Washington DC, has been appointed professor in the Departments of Physies and Biophysies, University of Chicago.

\section{Appointments}

Dr Ruth M. Davis, director of the Lister Hill National Center for Biomedical Communications, has been appointed director of the Center for Computer Sciences and Technology of the US National Bureau of Standards.

Sir Edward Bullard, University of Cambridge, Professor A. D. Bradshaw, University of Liverpool, and Dr C. E. Lucas, Department of Agriculture and Fisheries for Scotland, have all been appointed members of the Natural Environment Research Council.

The following have been elected officers of the International Astronautical Federation: president, Pro- fessor A. Jaumotte (Belgium), vice-presidents, Dr G. E. Mueller (USA), Mr H. G. S. Murthy (India), Professor L. G. Napolitano (Italy) and Professor L. I. Sedov (USSR).

An Academic Advisory Committee has been appointed to the Cranfield Institute of Technology to monitor and advise on academic standards. Members of the committee are: Lord Caldecote, Delta Metal Company (chairman); Mr H. F. R. Gatherwood, National Economic Development Couneil; Professor A. R. Collar; Sir George White, University of Bristol; Dr H. M. Finniston, British Steel Corporation; Dr F. R. Jones, Mullard Limited; Sir Morien Morgan, Royal Aircraft Establishment; Mrs M. K. McQuillan, Imperial Metal Industries (Kynoch) Limited; Professor S. C. Redshaw, University of Birmingham.

\section{Miscellaneous}

Professor Brinley Thomas, University College, Cardiff, has been awarded a fellowship by the US National Science Foundation.

The International Meteorological Organization prize for 1970 has been awarded posthumously to Professor R. Scherhag who was director of the Institute for Meteorology and Geophysies at the Free University of Berlin.

Dr Richard D. O'Brien, director of the Division of Biological Sciences at Cornell University, has won the 1970 International Award for Research in Pesticide Chemistry, sponsored by Burdick and Jackson Laboratories Inc., Muskegon, Michigan. 